Original Research Paper

\title{
A Comparative Study on the Information Effect of Stock Lending and Borrowing and Short Selling between the Korea Stock Exchange and the New Stock Exchange
}

\author{
${ }^{1}$ Yeongsuk Cho and ${ }^{2}$ Youngsik Kwak \\ ${ }^{1}$ College of Business Administration, Mokpo National University, Muan-gun, Jeonnam, South Korea \\ ${ }^{2}$ Department of Accounting, Economics and Finance, Delaware State University, Dover, Delaware, USA
}

\author{
Article history \\ Received: 26-04-2018 \\ Revised: 04-09-2018 \\ Accepted: 04-10-2018 \\ Corresponding Author: \\ Youngsik Kwak \\ Department of Accounting, \\ Economics and Finance, \\ Delaware State University, \\ Dover, Delaware, USA \\ Email : ykwak@desu.edu
}

\begin{abstract}
The purpose of this study is to compare the information effect of Stock Lending and Borrowing (SLB) and short selling between the Korea Stock Exchange (KRX) and the New York Stock Exchange (NYSE). While most previous studies analyzed the information effect with a focus on short selling, this study links short selling to SLB and examines how SLB and short selling affect stock prices. Using the data of 40 stocks with the most active records of SLB and short selling from each exchange, we perform a regression analysis to examine the information effect. We find that in the KRX, SLB has a positive effect on short selling and short selling has a negative effect on stock prices. However, in the NYSE, short selling has a significant positive effect on stock prices. This is due to the differences in policies concerning public posting of short selling data. We also find that the effect of volatility on stock prices and the effect of short selling on volatility are all significantly negative in both exchanges. That is, short selling reduces market volatility and thus keeps the market from overheating. Furthermore, the effects are greater during the periods when SLB and short selling are more concentrated.
\end{abstract}

Keywords: Information Effect, SLB, Short Selling, Korea Stock Exchange, New York Stock Exchange

\section{Introduction}

Investors in the stock market use various investment strategies to maximize their investment returns. Short selling has been one of the most commonly used strategy, which involves Stock Lending and Borrowing (SLB). Since the Korea Stock Exchange (KRX) banned naked short selling on stocks, SLB must take place before executing covered short selling. The KRX requires reporting of SLB and short selling transactions and posts the transaction information publicly. SLB and short selling transactions have been on a consistent rise and used with increasing frequency in the KRX.

The Korea Composite Stock Price Index (KOSPI) has repeated rises and falls within the range of 1,800 to 2,100 points during six years since 2010, with transaction amounts at a near standstill. Despite a weak KOSPI market, SLB and short selling transactions had steadily increased. During 2008-2015, the annual transaction amount increased by 2.4 times, the year-end balance by 4.1 times, the balance of stock lending by 5.4 times and the short selling transaction by more than 2 times. In the KRX, since Korean hedge funds was introduced at the end of 2011, an increasing number of Korean institutional investors have participated in short selling, compared to the past when foreign investors made up the majority. Furthermore, since November 14, 2013 when the ban on short sale of financial stocks was lifted, SLB and short selling have consistently increased.

Many previous studies (Boehmer et al., 2008; Bris et al., 2007; Harris et al., 2013; Beber and Pagano, 2013; Comerton-Forde et al., 2016b) have examined the information effect with a focus on short selling in the foreign stock markets. In the Korean stock market, however, a few studies have examined the relationship between SLB and short selling. For example, Eom et al. (2011) argue that foreign investors' short selling has no correlation with stock prices. Hwang and Cho (2011; 2012) show that SLB significantly affects volatility and increases liquidity. Cho and Hwang (2014) report that information effect of SLB exists in the Korean stock market. Cho and Kwak (2017) examine the situation 
before and after deregulation on short selling of KOSPI financial stocks and show that stock lending and borrowing and short selling have a significantly negative effect on information in the market.

This study differs from previous studies in two aspects. First, while most previous studies examine only the effect of short selling or the effect of SLB on the market, this study links short selling to SLB and examines how SLB and short selling affect stock prices. Second, the study conducts a comparative analysis of the information effect of SLB and short selling between the KRX and the NYSE.

\section{Latest Trends, Legal Framework and Review of Previous Studies}

\section{Latest Trends in SLB and Short Selling}

In the KRX, SLB and short selling transactions have been continuously increasing. As for the KOSPI, the average daily SLB volume of shares increased by 2.3 times to 25 million shares in 2014 from 11 million shares in 2010. From 2008 to 2014, the number of SLB shares increased 3.4 times to 1.13 billion shares and the amount 3.6 times to 37.6 billion dollars. Meanwhile, the short selling volume increased by more than two times from $1.5 \%$ in 2010 to $4 \%$ (which amounts to average 300 million dollars per day) by 2014, which shows the growing influence of short selling.

The number of SLB contract shares increased by 3.6 times to 5.37 billion shares in 2014 from 1.5 billion shares in 2008. As Fig. 1 shows, during the same period, the percentage of Korean investors (mostly institutional investors and securities firms) who participated in SLB transactions increased significantly. Both securities firms and asset management companies jumped into SLB transactions in late 2011 when Korean hedge funds were first introduced. Securities firms lending stocks accounted for $2.65 \%$ in 2008 to $25.6 \%$ in 2014 , while securities firms borrowing stocks increased from $6.4 \%$ to $30.4 \%$. During the same period, the volume of stocks loaned by asset management companies increased from $4.2 \%$ to $7.3 \%$. These companies started stock borrowing in 2011 and the volume of their stock borrowing increased from $2.4 \%$ to $4.8 \%$ in 2014 .

In SLB transactions, both the lender and the borrower have an opportunity to make a profit. In addition, they earn about 2 to $4 \%$ in transaction fees (fees on lending, borrowing and brokerage). Longterm investors who do not plan to sell their stocks over the short term can lend their stocks to others, thereby making additional income.

The Korea Securities Depository serves as an intermediary in most SLB transactions in the KRX and publishes annual reports of SLB transactions as shown in Table 1 . In the past 7 years, the transaction amounts in SLB rose drastically to 90.6 billion dollars in 2010 from a low point of 62.3 billion dollars in 2009 , marking a $45.5 \%$ jump. Since then, the rise has continued and the transaction amount recorded 150.7 billion dollars in 2014, which represents a $240 \%$ increase over five years. These increases may be explained by the lift on short selling ban (June, 2009) that had been imposed since the financial crisis in 2008 and by the introduction of Korean hedge funds in late 2011 along with a promotion of domestic prime brokers to support the Korean hedge fund market.

Proportion of Investors Lending Stocks in SLB

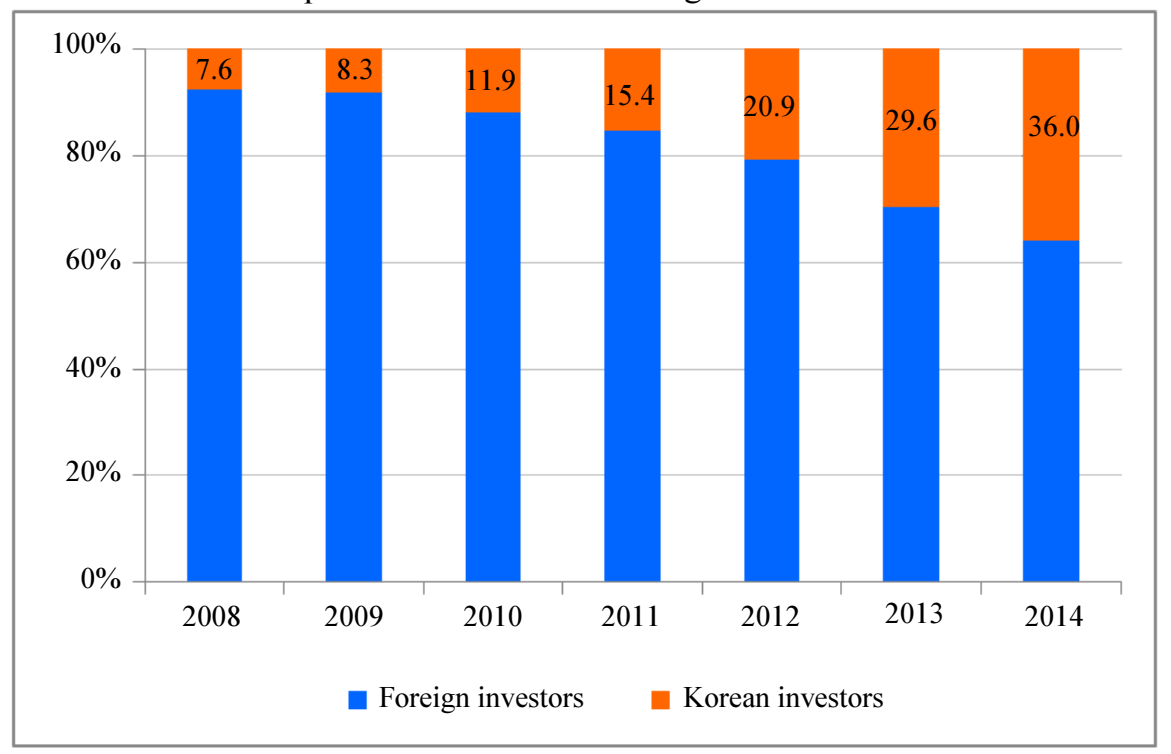




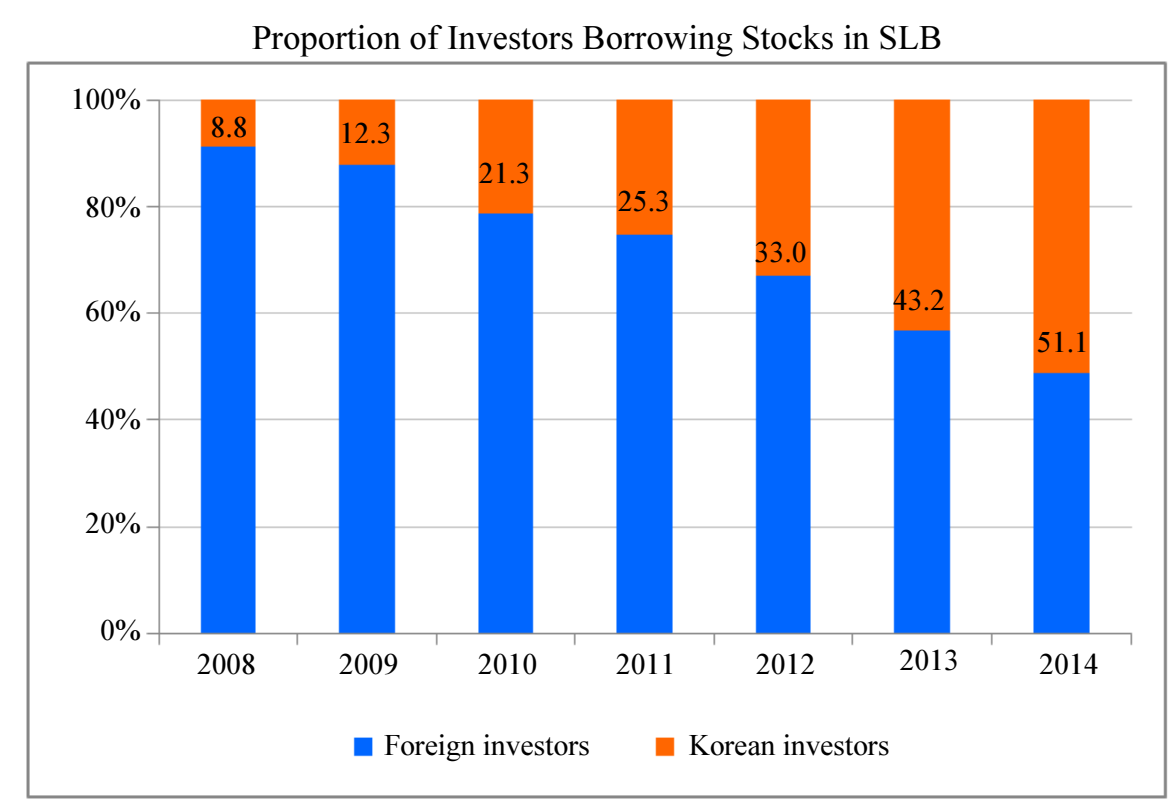

Fig. 1: Proportional Trend of Korean investors in SLB transactions in the KRX

Table 1: SLB Transactions from 2008 to 2014 (unit: million share, million dollar)

\begin{tabular}{|c|c|c|c|c|c|c|c|c|}
\hline & \multicolumn{2}{|l|}{ Amount } & \multicolumn{2}{|c|}{ Volume } & \multicolumn{4}{|c|}{ Balance of SLB } \\
\hline & Amount & Growth rate & Share & Growth rate & Share & Growth rate & Amount & Growth rate \\
\hline 2008 & 109,707 & - & 2,623 & - & 272 & & 9,861 & - \\
\hline 2009 & 62,282 & $-43.2 \%$ & 1,495 & $-43.0 \%$ & 203 & $-25.3 \%$ & 9,616 & $-2.5 \%$ \\
\hline 2010 & 90,590 & $45.5 \%$ & 1,666 & $11.4 \%$ & 205 & $0.9 \%$ & 10,124 & $5.3 \%$ \\
\hline 2011 & 112,689 & $24.4 \%$ & 1,914 & $14.9 \%$ & 270 & $31.8 \%$ & 12,655 & $25.0 \%$ \\
\hline 2012 & 126,868 & $12.6 \%$ & 2,340 & $22.3 \%$ & 490 & $81.2 \%$ & 19,079 & $50.8 \%$ \\
\hline 2013 & 142,901 & $12.6 \%$ & 2,974 & $27.1 \%$ & 658 & $34.3 \%$ & 24,409 & $27.9 \%$ \\
\hline 2014 & 150,731 & $5.5 \%$ & 3,743 & $25.9 \%$ & 1,014 & $54.1 \%$ & 34,079 & $39.6 \%$ \\
\hline
\end{tabular}

*Source: Korea Securities Depository (KSD), Yearly Data Arrangement (www.seibro.or.kr)

Short selling offers some benefits. First, it improves the efficiency of price determination. Given the risks associated with short selling, short sellers are generally informed investors and thus help prices reflect all available information in the market. Second, short selling associated with arbitrage contributes to resolve the price gap between derivatives and underlying assets. On the other hand, short selling may increase volatility in the market and has the risk of unlimited loss when the price goes up. Some investors argue that short selling should be regulated because it disrupts the market. As such, regulations on short selling seek to strike a balance between the benefits and the risks. Given their unique environments, stock exchanges around the world utilize an appropriate public notice system to ensure fair and transparent communication of information, which helps maintain an orderly market. The KRX distinguishes between naked short selling (where stocks are not borrowed) and covered short selling (where stocks are borrowed) and naked short selling has been banned since March 2000.

Figure 2 shows how SLB is connected to short selling. Covered short selling involves borrowing and selling securities and buying back the same securities later to cover the short position. Even though short selling is applicable to transactions of all investment assets, it is especially beneficial when it involves financial assets (such as stocks, foreign currencies or bonds) with high liquidity and standardization. The main advantage of short selling is that it allows investors to profit from a drop in price. Short sellers, expecting the stock price to fall, sell borrowed stocks and repurchase the same stocks to cover the short position when the stock price falls as expected. Thus, they make profit from a price decline. 


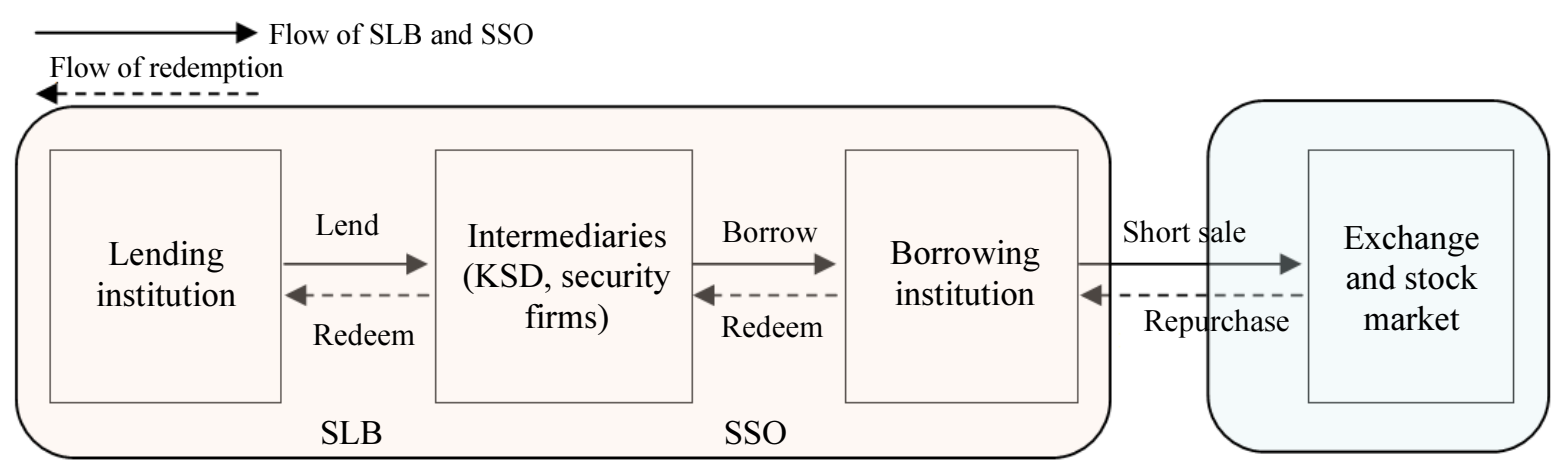

Fig. 2: Flow of SLB and Short Selling Transactions

Table 2: Legal Framework of SLB and Short Selling: KRX Vs NYSE

\begin{tabular}{|c|c|c|}
\hline & KRX & NYSE \\
\hline SLB & $\begin{array}{l}\text { - Mostly foreign investors or institutional investors } \\
\text { participate in the transactions. } \\
\text { - The KOFIA compiles and publicly posts information by } \\
\text { category, date, transaction details and short interest (Korea } \\
\text { Securities Depository only posts its own performance). }\end{array}$ & $\begin{array}{l}\text { - Most transactions done by institutional investors. } \\
\text { - No official compilation or public posting. }\end{array}$ \\
\hline Short selling & $\begin{array}{l}\text { - Only covered short selling allowed. } \\
\text { - KRX publicly posts the transaction details by category } \\
\text { and date (Short interest is not posted). } \\
\text { - Public posting policies implemented for short interest } \\
\text { (as of July 2016). }\end{array}$ & $\begin{array}{l}\text { - Both covered short selling and naked short selling allowed. } \\
\text { - Short interest is publicly posted twice a month (on the 15th }\end{array}$ \\
\hline Price range limit & Adjusted to $\pm 30 \%$ on June 15,2015 & No price range limit \\
\hline
\end{tabular}

Since the KRX prohibits naked short selling, it is required to borrow stocks from a lending institution through a SLB transaction for short selling. In a SLB transaction, investors borrow stocks with a promise to return the stocks after a certain period. The lender, in exchange, receives fees of 2 to $4 \%$ per annum. The borrower may execute short selling transactions for profit, arbitrage (or non-arbitrage), hedging, re-lending the stocks to another investor at a higher fee, or for settling the previous short selling. In addition, short selling may be used for various investment strategies associated with bonds or derivatives to provide liquidity to the market related to Equity-Linked Warrants (ELW), Equity-Linked Securities (ELS), Exchange-Traded Funds (ETF), futures or options. Therefore, SLB transactions in the KRX do not necessarily have a negative impact on the stock market. Moreover, short selling can be executed through program trading, but the KRX requires program traders to publicly post the type of program transactions (e.g., hedging transaction, arbitrage or non-arbitrage transaction, short selling through stock borrowing.)

\section{Differences in SLB and Short Selling Legal Framework between KRX and NYSE}

For an in-depth analysis, this study examines differences in the legal framework concerning SLB and short selling between the KRX and NYSE. Table 2 shows a summary of the differences. These differences can lead to differences in the effect of SLB and short selling, market reaction and asset management strategy.

In the meanwhile, the KRX began to deregulate and increased the daily stock price limit to $30 \%$ on June 15 , 2015 , which in fact has a similar effect of no daily price limit and deregulation has taken place. Furthermore, responding to complaints about short selling regulations by individual investors, the KRX adopted a policy of reporting the balance of high volume short selling transactions. While SLB transactions are used for different purposes, they are frequently used for covered short selling. Since short selling implies a negative signal on the stock price and thus greatly affects investor sentiment, the KRX publicly posts daily transaction volume and amount of borrowed securities and short selling for every index and category (Different from the NYSE, KRX does not publicly post the short interest but post only the daily amount and volume of short selling transactions). As the KRX keeps abreast with the short sale regulations of the NYSE, the information effects of short selling in both exchanges may have little difference in the long run.

\section{Review of Previous Studies}

Preceding studies on short selling are abundant in Korea or abroad but there are only a limited number of 
studies on SLB. For example, Aitken et al. (1998), Nagel (2005), Chang et al. (2007), Cohen et al. (2007) and Boehmer et al. (2008) report that short selling lead to overvaluation or improve information efficiency on negative information. Allen et al. (1992), Jones and Lamont (2002) and Boehme et al. (2006) note that restrictions on stock short selling leave room for overvaluation and could create a stock price bubble. They argue that in such a case, the speed at which negative information affects the market could be slowed down to cause a market crash. Moreover, Henry and McKenzie (2006) and Chang et al. (2007) argue that since negative information is actively produced via stock short selling, short selling is positively correlated with the frequency of negative returns and volatility on an individual stock basis. Diether et al. (2009) analyze the effect of the uptick rule and present the results.

Many studies have examined the reinforced regulations on short selling during the financial crisis of 2008. For example, Autore et al. (2009) and Harris et al. (2013) analyze that limits placed on short selling causes stock prices to be over-evaluated. Bris et al. (2007) and Beber and Pagano (2013) report that short selling undermines price efficiency. Meanwhile, Boehmer et al. (2008) and Boulton and Braga-Alves (2010) argue that short selling undermined liquidity and market quality. According to these studies, results vary depending on the study methodology and data analyzed. However, they all bring into question the effectiveness of regulations on short selling and call for authorities to take a more prudent approach. Hurtado Sanchez (1978) examine the American market and show that SLB is correlated with speculative motivations. Brent et al. (1990) report through a cross-sectional regression analysis that the motivations for SLB are highly correlated with arbitrage transactions and hedging, while tax motivations and speculative motivations are weak. Kaplan et al. (2013), through experiments, shows that SLB affects short selling supplies and does not have an inverse effect on stock prices. Adams et al. (2014) discover that sponsor-affiliated lending agents have a lower return, while the return from securities lending is significantly higher when the funds managed their own loan programs. A larger number of directors owning funds is correlated with a greater level of independence of the board and a larger number of directors and a smaller bonus compensation for directors are correlated with higher loan returns.

Studies in Korea include those by Kim (2000) on lending stocks. Kim and Bin (2009) report that short selling of stocks does not have a significant effect on stock market indices and note that the real effects on the foreign exchange market would also be very subtle. Kim (2010) analyzes the effects of short selling restrictions and reports that there is no evidence of stock prices being over-evaluated or liquidity worsening, but some evidence of worsening price efficiency. Cho and Kwak (2017), analyzing the differences of stock market returns before and after the short selling ban, show that stock lending and borrowing and short selling systems supply the market with significant information contents.

Empirical studies on stock lending and borrowing include the study by Song (2006) that analyzes the performance of stock lending and borrowing from 2000 to 2002 , but the study analyzes the initial market when such transactions are few and foreign investors rarely participate in SLB transactions. Meanwhile, Hwang and Cho (2011) analyze the data from 459 days during 2008 and 2009 and reported that stock lending and borrowing were done mostly by foreign investors, that the effects of new loan transactions were greater than repayment transactions and that such transactions had a significant effect on volatility and were highly correlated with speculative transaction motivations associated with short selling. Cho and Hwang (2014) show that stock lending and borrowing provides beneficial information to the market.

\section{Research Methodology}

\section{Sample Selection and Data}

The study sample consists of a portfolio of 40 stocks with the most active SLB and short selling transactions from each exchange (the KRX and NYSE) (We selected the top 40, in terms of transaction volume, out of 773 stocks listed in the KRX as of December 2014. The top 40 stocks account for more than $80 \%$ of stock lending and borrowing volume and more than $60 \%$ of the short selling volume. During the seven-year period, SLB volume ranges from $80.3 \%$ to $86.2 \%$ and short selling volume from $63.2 \%$ to $72.5 \%$ ). The study period includes 7 years from January 2008 to December 2014 . In January 2008, SLB and short selling trading led by foreign investors, began to increase drastically.

Data on stock prices and short selling are collected from the KRX (http://marketdata.krx.co.kr), while SLB transactions data are obtained from the KOFIA (http://freesis.or.kr). SLB and short selling transactions are publicly posted daily on the KOFIA and KRX websites. Data on stock prices and short selling on NYSE are collected from the weekly data of Bloomberg. To compare the effects of SLB and short selling in the KRX and the NYSE, daily transactions in the KRX are adjusted to biweekly data. This adjustment is necessary to align with the NYSE reporting dates. The NYSE publicly posts the short interests twice every month (on the $15^{\text {th }}$ and the last day of each month) (There are subtle differences in the publicly posted information on short selling. While the NYSE posts the short interests twice a 
month, the KRX posts the volume and amount of short selling transactions daily).

\section{Selection of Variables}

To measure the information effects, we select the following variables for the regression model:

$$
\begin{aligned}
& \text { Lending and Borrow Rate }(L B R) \\
& =\frac{\text { Bi-weekly new lending and borrowing shares }}{\text { Averagebi }- \text { weeklyvolume }} \\
& \text { Redemption Degree Rate }(R D R) \\
& =\frac{\text { Bi-weekly redemption shares }}{\text { Averagebi }- \text { weeklyvolume }}
\end{aligned}
$$

Lending and Borrowing Growth Rate (LBGR)

$=\frac{\text { Weekly (short selling - redemption) shares }}{\text { Balance of SLB volume as of prior weekend }}$

Short - selling Rate $(S S R)=\frac{\text { Bi-weekly short selling shares }}{\text { Averagebi }- \text { weeklyvolume }}$

$$
\text { Volatility }(\text { VOL })=\frac{(\text { Highest }- \text { lowest }) \text { price during } 2 \text { weeks }}{\text { Priceas of prior weekend }}
$$

Rate of Return $(R R)=B i-$ weekly rate of returen

The first three variables (LBR, RDR and LBGR) are related to SLB transactions and are selected to examine their possible effects on SSR, VOL and RR (Cho and Hwang (2014)). Previous studies have shown that SSR and VOL are correlated with stock prices (e.g., Henry and McKenzie (2006) and Chang et al. (2007)).

\section{Research Hypotheses}

The information-based trading theory argues that foreign and institutional investors execute SLB and short selling trading to maximize investment returns when the price is expected to fall after the short selling. Informed investors execute stock borrowing and short selling trading once they acquire superior information. Specifically, before the 2008 global financial crisis, stock prices plunged partly due to a large-scale net selling of stocks by foreign investors. In fact, in the same this period, there was a significant increase in SLB and short selling transactions by foreigner investors. However, over the four months (September to December 2008), when stock prices took a nosedive following the global financial crisis, there was a drastic fall in SLB transactions (The balance of SLB as registered by the Korea Securities Depository was $\$ 3.72$ billion at the end of $2005, \$ 6.25$ billion at the end of 2006 , $\$ 15.7$ billion at the end of 2007 and $\$ 31.1$ billion at the of end of August, 2008, indicating a drastic increase over the period. However, during the four months of September to December, 2008 when the KOSPI nosedived, the balance dropped by $\$ 21.3$ billion KRW (new loans of $\$ 27$ billion and redemption of loans by $\$ 48.3$ billion), to $\$ 9.86$ billion at the end of 2008 . Refer to Hwang and Cho (2011) for details).

This indicates there exists information asymmetry among investors. As a result, such transactions lead to significant information effects. To analyze the information effects of SLB and short selling, this study develops the following hypotheses (in the alternate form) to be tested in the KRX:

- Hypothesis 1 (H1): LBR has a positive effect on SSR

- Hypothesis 2 (H2): LBR and LBGR have a negative effect on RR

- Hypothesis 3 (H3): SSR has a negative effect on RR

- Hypothesis 4 (H4): VOL has a positive effect on RR

- Hypothesis 5 (H5): SSR, LBR and RDR have a negative effect on VOL

Due to constraints in the data, only the last three hypotheses will be tested in the NYSE as follows:

- Hypothesis 3 (H3): SSR has a negative effect on RR

- Hypothesis 4 (H4): VOL has a positive effect on RR

- Hypothesis 5 (H5): SSR has a negative effect on VOL

\section{Regression Equations}

To test the hypotheses, we estimate the following regression models:

$$
\begin{aligned}
& S S R_{t}=a+b_{1}\left(L B R_{t}\right)+b_{2}\left(R D R_{t}\right)+b_{3}\left(L B G R_{t}\right)+e_{t} \\
& R R_{t}=a+b_{1}\left(L B R_{t}\right)+b_{2}\left(R D R_{t}\right)+b_{3}\left(L B G R_{t}\right)+e_{t} \\
& R R_{t}=a+b_{1}\left(L B R_{t}\right)+b_{2}\left(R D R_{t}\right)+b_{3}\left(L B G R_{t}\right)++_{4}\left(S S R_{t}\right)+e_{t} \\
& R R_{t}=a+b_{1}\left(L B R_{t}\right)+b_{2}\left(R D R_{t}\right) \\
& +b_{3}\left(L B G R_{t}\right)+b_{4}\left(S S R_{t}\right)+b_{5}\left(V O L_{t}\right)+e_{t} \\
& V O L_{t}=a+b_{1}\left(L B R_{t}\right)+b_{2}\left(R D R_{t}\right) \\
& +b_{3}\left(L B G R_{t}\right)+b_{4}\left(S S R_{t}\right)+e_{t} \\
& R R_{t}=a+b_{1}\left(S S R_{t}\right)+e_{t} \\
& R R_{t}=a+b_{1}\left(S S R_{t}\right)+b_{2}\left(V O L_{t}\right)+e_{t} \\
& V O L_{t}=a+b_{1}\left(S S R_{t}\right)+e_{t}
\end{aligned}
$$

We first conduct a regression analysis on the related variables for the entire sample period (2008 2014). 
Then, the period is divided into four quartiles by the volume of trading, the first quartile (Q1) being the most concentrated period and the fourth quartile (Q4) the least concentrated period. We perform further regression analysis for the two sub periods to examine the difference in the information effect between Q1 and Q4.

\section{Empirical Results}

\section{Descriptive Statistics}

Table 3 and 4 show descriptive statistics on the variables concerning SLB and short selling. In Table 4, LBR has a relatively high positive correlation with RDR and SSR.

Table 3: Descriptive Statistics: KRX

\begin{tabular}{llllrrr}
\hline & Mean & Std. Dev. & Maximum & Minimum & Skewers & Kurtosis \\
\hline Lending and Borrowing Growth Rate (LBGR) & -0.0001 & 0.0224 & 0.2014 & -0.3773 & -1.5827 & 37.1429 \\
Lending and Borrowing Rate (LBR) & 0.1426 & 0.1543 & 2.6368 & 0.0000 & 4.0787 & 38.6504 \\
Redemption Rate (RDR) & 0.1436 & 0.1714 & 3.3829 & 0.0000 & 5.4067 & 63.6657 \\
Rate of Return (RR) & 0.0066 & 0.1209 & 0.6569 & -0.5729 & 0.8374 & 8.1344 \\
Short-selling Rate (SSR) & 0.0366 & 0.0351 & 0.2861 & 0.0000 & 2.0278 & 9.3536 \\
Volatility (VOL) & 0.0863 & 0.0588 & 0.7774 & 0.0000 & 3.3611 & 24.6659 \\
\hline
\end{tabular}

Table 4: Coefficient of Correlation

\begin{tabular}{|c|c|c|c|c|c|c|}
\hline & LBGR & LBR & RDR & RR & SSR & VOL \\
\hline Lending and Borrowing Growth Rate (LBGR) & 1.0000 & & & & & \\
\hline Lending and Borrowing Rate (LBR) & 0.2374 & 1.0000 & & & & \\
\hline Redemption Rate (RDR) & -0.2828 & 0.6411 & 1.0000 & & & \\
\hline Rate of Return (RR) & 0.0036 & -0.0121 & -0.0071 & 1.0000 & & \\
\hline Short-selling Rate (SSR) & 0.1557 & 0.5035 & 0.3191 & -0.0161 & 1.0000 & \\
\hline Volatility (VOL) & 0.0051 & -0.1132 & -0.1388 & -0.1160 & -0.0811 & 1 \\
\hline
\end{tabular}

Table 5: Regression Results: KRX

\begin{tabular}{|c|c|c|c|c|c|c|c|c|c|}
\hline & & \multirow{2}{*}{$\begin{array}{l}\text { Dependent } \\
\text { Variable }\end{array}$} & \multirow[b]{2}{*}{ C } & \multicolumn{5}{|c|}{ Independent Variable } & \multirow[b]{2}{*}{$\mathrm{R}^{2}$} \\
\hline & & & & LBR & RDR & LBGR & SSR & VOL & \\
\hline \multirow[t]{5}{*}{ Total Period } & $\mathrm{H} 1$ & SSR & 0.020 & $\begin{array}{l}0.106^{* * *} \\
(19.88)\end{array}$ & $\begin{array}{l}0.007 \\
(1.40)\end{array}$ & $\begin{array}{l}0.084^{* * *} \\
(2.85)\end{array}$ & & & 25.5 \\
\hline & H 2 & $\mathrm{RR}$ & 0.008 & $\begin{array}{l}-0.016 \\
(-0.76)\end{array}$ & $\begin{array}{l}0.007 \\
(0.34)\end{array}$ & $\begin{array}{l}0.061 \\
(0.51)\end{array}$ & & & 2.0 \\
\hline & H 3 & $\mathrm{RR}$ & 0.009 & $\begin{array}{l}-0.011 \\
(-0.49)\end{array}$ & $\begin{array}{l}0.007 \\
(0.35)\end{array}$ & $\begin{array}{l}0.065 \\
(0.55)\end{array}$ & $\begin{array}{l}-0.048 \\
(-0.70)\end{array}$ & & 3.1 \\
\hline & $\mathrm{H} 4$ & $\mathrm{RR}$ & 0.032 & $\begin{array}{l}-0 . .012 \\
(-0.53)\end{array}$ & $\begin{array}{l}-0.004 \\
(-0.21)\end{array}$ & $\begin{array}{l}0.048 \\
(0.41)\end{array}$ & $\begin{array}{l}0.061 \\
(-0.89)\end{array}$ & $\begin{array}{l}-0.245^{* * *} \\
(-6.92)\end{array}$ & 1.4 \\
\hline & H 5 & VOL & 0.095 & $\begin{array}{l}-0.003 \\
(-0.24)\end{array}$ & $\begin{array}{l}-0.045 \\
(-4.79)\end{array}$ & $\begin{array}{l}-0.067 \\
(-1.18)\end{array}$ & $\begin{array}{l}-0.053 \\
(-1.60)\end{array}$ & & 2.2 \\
\hline \multirow[t]{5}{*}{$\begin{array}{l}\text { Most Concentrated } \\
\text { Period (Q1) }\end{array}$} & H 1 & SSR & 0.069 & $\begin{array}{l}0.080^{* * *} \\
(10.79)\end{array}$ & $\begin{array}{l}-0.008 \\
(-1.01)\end{array}$ & $\begin{array}{l}0.224 \\
2.84)\end{array}$ & & & 15.2 \\
\hline & $\mathrm{H} 2$ & $\mathrm{RR}$ & 0.011 & $\begin{array}{l}0.039 \\
(-0.95)\end{array}$ & $\begin{array}{l}0.031 \\
(0.77)\end{array}$ & $\begin{array}{l}0.275 \\
(0.746)\end{array}$ & & & 1.2 \\
\hline & H 3 & $\mathrm{RR}$ & 0.455 & $\begin{array}{l}-0.006 \\
(1.05)\end{array}$ & $\begin{array}{l}0.027 \\
(0.66)\end{array}$ & $\begin{array}{l}0.388 \\
(-0.15)\end{array}$ & $\begin{array}{l}-0.503^{* * *} \\
(-3.13)\end{array}$ & & 3.2 \\
\hline & $\mathrm{H} 4$ & RR & 0.066 & $\begin{array}{l}-0009 \\
(-0.21)\end{array}$ & $\begin{array}{l}0.020 \\
(0.51)\end{array}$ & $\begin{array}{l}0.451 \\
(1.23)\end{array}$ & $\begin{array}{l}-0.473^{* * *} \\
(-2.95)\end{array}$ & $\begin{array}{l}-0.259^{* * *} \\
(-2.66)\end{array}$ & 2.2 \\
\hline & H 5 & VOL & 0.080 & $\begin{array}{l}-0.010 \\
(0.65)\end{array}$ & $\begin{array}{l}-0.024^{*} \\
(-1.68)\end{array}$ & $\begin{array}{l}0.257^{* *} \\
(1.98)\end{array}$ & $\begin{array}{l}-0.101^{*} \\
(-1.78)\end{array}$ & & 4.1 \\
\hline \multirow[t]{5}{*}{$\begin{array}{l}\text { Least Concentrated } \\
\text { (Q4) Period }\end{array}$} & H 1 & SSR & 0.004 & $\begin{array}{l}0.011^{* * *} \\
(4.05)\end{array}$ & $\begin{array}{l}0.004^{*} \\
(1.94)\end{array}$ & $\begin{array}{l}-0.002 \\
(-0.37)\end{array}$ & & & 6.3 \\
\hline & H 2 & RR & 0.004 & $\begin{array}{l}0.021 \\
(0.37)\end{array}$ & $\begin{array}{l}-0.051 \\
(-1.17)\end{array}$ & $\begin{array}{l}-0.095 \\
(-0.63)\end{array}$ & & & 2.0 \\
\hline & H 3 & RR & 0.002 & $\begin{array}{l}0.016 \\
(0.27)\end{array}$ & $\begin{array}{l}-0.052 \\
(-1.21)\end{array}$ & $\begin{array}{l}-0.094 \\
(-0.63)\end{array}$ & $\begin{array}{l}0.493 \\
(0.65)\end{array}$ & & 2.5 \\
\hline & $\mathrm{H} 4$ & RR & 0.032 & $\begin{array}{l}0.042 \\
(0.75)\end{array}$ & $\begin{array}{l}-0.071^{*} \\
(-1.65)\end{array}$ & $\begin{array}{l}0.183 \\
(-0.22)\end{array}$ & $\begin{array}{l}-0.553 \\
(-0.72)\end{array}$ & $\begin{array}{l}-0.237^{* * *} \\
(-5.11)\end{array}$ & 3.3 \\
\hline & H 5 & VOL & 0.125 & $\begin{array}{l}0.12 \\
(2.67)\end{array}$ & $\begin{array}{l}-0.076^{* *} \\
(-2.34)\end{array}$ & $\begin{array}{l}-0.388^{* * *} \\
(-3.56)\end{array}$ & $\begin{array}{l}-4.346^{* * *} \\
(-7.98)\end{array}$ & & 8.5 \\
\hline
\end{tabular}

Note: t-values are shown in parentheses and $*, * *, * * *$ indicate $10 \%, 5 \%$ and $1 \%$ significance level, respectively 


\section{Results of Hypothesis Testing}

Table 5 presents the results of testing Hypothesis 1 through 5 in the KRX.

First, we estimate Equation (1) separately for the entire period and two sub periods. The result show that LBR and LBGR have a positive effect on SSR at a $1 \%$ significance level. In both the entire period and the concentrated period, the results are significant. In the concentrated period, the regression coefficient of LBGR is greater than that of LBR, indicating that LBGR has a greater effect. Meanwhile, in the least concentrated period, LBR is significant at $1 \%$ but RDR was significant at $10 \%$. This result lends support to Hypothesis 1.

Second, the result of estimating Equation (2) shows that $L B R$, RDR and LBGR are found to have no significant effect on RR. The result indicates that SLB transactions indirectly affect the stock price through short selling. That is, in the KRX, SLB are used not only for short selling but also for redemption of outstanding SLB, ELW and derivative-related SLB transactions. On average, about $30 \%$ of SLB are used for short selling. The result does not support Hypothesis 2.

Third, the result of Equation (3) estimation shows SLB are not correlated with RR, but SSR has a significant negative correlation with RR at a significance level of $1 \%$ only for the most concentrated period. This evidence indicates that during the time when short selling is concentrated, the increase in supply of the stocks can push down the stock prices. This finding is in line with the empirical results reported in the study of Comerton-Forde et al. (2016a), which show that short flow is strongly related to a stock's return. However, for the least concentrated period, the coefficient on SSR is large, but is not statistically significant. The result support Hypothesis 3 only for the period during short selling is most concentrated.

Fourth, the estimation of Equation (4) shows that VOL has a negative correlation with $R R$ at a significance level of $1 \%$. This result is similar to the findings of Wu et al. (2018) which show that short sale decreases return-volatility correlation. In addition, SSR has a significant negative correlation with RR, but none of the SLB variables (LBR, RDR and LBGR) has a significant correlation with RR. This result does not lend support to Hypothesis 4 .

Lastly, the estimation result of Equation (5) shows that SSR has a negative effect on VOL, but the effect was statistically significant at a $1 \%$ level only for the least concentrated period. The result also shows that RDR had a significant negative correlation with VOL, which indicates that RDR has a market stabilizing effect by reducing price volatility. This is consistent with the findings of Cho and Hwang (2014) who show that loan redemption continues to have a positive effect in the KRX. Over a short period, RDR usually has a higher correlation with short selling than new LBR has (In the KRX, new LBR generally have a longer maturity of 6 months (up to one year, or within the promised period). However, after short selling transactions, it is more than likely to buy back stocks to cover the short position in a short period). In addition, RDR occurs more frequently when (or after) stock prices fall. Even when stocks record a new high, due to the risk of additional increase in the stock prices, redemption is required to cover the short position. Therefore, RDR occurring after a sufficient drop in stock prices indicate a shift to the trend of rising stock prices. Meanwhile, in cases where redemption occurs on stocks with a new high, there is a high likelihood of additional price increases. This result marginally support Hypothesis 5. In addition, the result is in line with the findings of Cho and Kwak (2017) who noted that in concentrated periods, LBR affects SSR. The analysis of RDR shows that it affects volatility likewise.

Table 6 presents the results of testing Hypothesis 3, 4 and 5 in the NYSE.

First, the estimation of Equation (6) shows that SSR has a significant positive effect on RR at a significance level of $1 \%$ for the total period, but not for the sub periods. This result does not support Hypothesis 3 .

Second, the estimation of Equation (7) shows that the effect of VOL on RR is significant at a $1 \%$ level, which does not lend support Hypothesis 4.

Finally, the estimation of Equation (8) shows that SSR has a negative effect on VOL at a significance level of $1 \%$, which supports Hypothesis 5 . This indicates that short selling mitigates market volatility. When stock prices are deemed overheated, short selling frequently occurs and serves as a market stabilizing force. This is evidence of the positive function of short selling that prevents the market from overheating. However, when the market tanks during a financial crisis, short selling has been banned citing the risk of increased volatility. Therefore, a more detailed analysis would be required.

Table 7 summarizes the differences between the KRX and NYSE. LBR and SSR are found to have a significant effect on providing information to the market. That is, in the KRX, LBR has a significantly positive effect on short selling, which in turn has a significantly negative effect on stock prices.

Regarding Hypothesis 3, the effect of short selling on stock prices are opposite in the KRX and NYSE. This is due to the difference in public posting policies for short selling and the qualitative differences in the two markets. The difference in information provided through public posting can lead to differences in market reactions. While the KRX announces the volume of short selling transactions daily, the NYSE posts the short interests twice per month. 
Table 6: Regression results: NYSE

\begin{tabular}{|c|c|c|c|c|c|c|}
\hline & & \multirow[b]{2}{*}{$\begin{array}{l}\text { Dependent } \\
\text { Variable }\end{array}$} & \multirow[b]{2}{*}{ C } & \multicolumn{2}{|c|}{ Independent Variable } & \multirow[b]{2}{*}{$\mathrm{R}^{2}$} \\
\hline & & & & SSR & VOL & \\
\hline \multirow[t]{3}{*}{ Total Period } & H 3 & $\mathrm{RR}$ & -0.002 & $\begin{array}{l}0.423^{* * *} \\
(3.08)\end{array}$ & \multirow{3}{*}{$\begin{array}{l}-0.293^{* * *} \\
(-7.28)\end{array}$} & 7.5 \\
\hline & H 4 & $\mathrm{RR}$ & -0.002 & $\begin{array}{l}0.218 \\
(1.59)\end{array}$ & & 2.2 \\
\hline & H 5 & VOL & 0.083 & $\begin{array}{l}-0.699^{* * *} \\
(-7.42)\end{array}$ & & 4.2 \\
\hline \multirow[t]{3}{*}{ Most Concentrated period (Q1) } & H 3 & RR & 0.103 & $\begin{array}{l}0.006 \\
(0.10)\end{array}$ & \multirow{3}{*}{$\begin{array}{l}-0.181^{* * *} \\
(-4.21)\end{array}$} & 1.0 \\
\hline & $\mathrm{H} 4$ & RR & 0.196 & $\begin{array}{l}-0.028 \\
(-0.44)\end{array}$ & & 1.4 \\
\hline & H 5 & VOL & 0.052 & $\begin{array}{l}-0.191^{* * *} \\
(-4.64)\end{array}$ & & 6.3 \\
\hline \multirow[t]{3}{*}{ Least Concentrated period (Q4) } & H 3 & RR & -0.026 & $\begin{array}{l}1.981 \\
(2.78)\end{array}$ & \multirow{3}{*}{$\begin{array}{l}-0.333^{* * *} \\
(8.92)\end{array}$} & 0.6 \\
\hline & H 4 & $\mathrm{RR}$ & 0.016 & $\begin{array}{l}0.395 \\
(0.55)\end{array}$ & & 6.5 \\
\hline & H 5 & VOL & 0.130 & $\begin{array}{l}-4.758^{* * *} \\
(-9.14)\end{array}$ & & 6.2 \\
\hline
\end{tabular}

Note) t-values are shown in parentheses and $*, * *, * * *$ indicate $10 \%, 5 \%$ and $1 \%$ significance level, respectively.

Table 7: Comparison of Information Effects between the KRX and NYSE

\begin{tabular}{|c|c|c|c|c|}
\hline & $\begin{array}{l}\text { Independent } \\
\text { Variable }\end{array}$ & $\begin{array}{l}\text { Dependent } \\
\text { Variable }\end{array}$ & KRX & NYSE \\
\hline Hypothesis 1 & SLB & Short selling & + & N/A \\
\hline Hypothesis 2 & SLB & Stock Price & - (Not significant) & N/A \\
\hline Hypothesis 3 & Short selling & Stock Price & - & + \\
\hline Hypothesis 4 & Volatility & Stock Price & - & - \\
\hline Hypothesis 5 & Short selling & Volatility & - & - \\
\hline
\end{tabular}

As for Hypothesis 4 and 5, the effect of VOL on stock prices and the effect of SSR on VOL has a negative correlation with information effects in both the KRX and NYSE. This indicates that short selling occurs often when stock prices are deemed overheated; short selling has a market stabilizing effect. This can prove the positive effect of short selling that prevents overheating in the market. RDR, too, is shown to ease VOL.

In summary, in the KRX, it is proven that foreign, institutional and professional investors use short selling with SLB to maximize their investment returns. Moreover, the market may experience a short-term drop in stock prices after a high volume of SLB and short selling transactions.

\section{Conclusion and Recommendations}

This study conducted a comparative study on the information effect of SLB and short selling between the KRX and the NYSE. While most preceding studies analyze with a focus on short selling, this study links short selling with SLB to identify cross-border differences.

The study sample consists of a portfolio of 40 stocks with the most active SLB and short selling transactions in the KRX and the NYSE. The study period includes seven years from January 2008 to December 2014. For additional analysis, the sample period is divided into four sub periods (Q1-Q4) by the volume of transactions, with Q1 being the highest volume period. Using the data and relevant variables, we conduct a regression analysis to analyze the information effect of SLB and short selling.

In summary, in the KRX, SLB has a positive effect on short selling and short selling has a negative effect on stock prices. In the meanwhile, stock prices are not affected by LBR, RDR and LBGR, which may indicate that new LBR contracts indirectly affect the stock prices through short selling. In the NYSE, however, short selling has a significant positive effect on stock prices. This is due to the differences in policies concerning public posting of short selling data. Further study is warranted once the KRX changes policies on short selling.

Second, the effect that volatility has on stock prices and the effect that short selling has on volatility are all significantly negative in the KRX and the NYSE. That is, short selling reduces market volatility, preventing an overheated market.

Third, the effects of these variables are consistent overall, but are more distinct during the period when SLB and short selling are most concentrated. 
We draw two policy recommendations from the results of this study. First, SLB and short selling is a valuable investment strategy since they are one of the major factors affecting stock prices. In fact, foreign and institutional investors actively use them to maximize their investment returns. To help domestic investors make informed decisions in the Korea stock market, we need to provide the market with more accurate and sufficient information about SLB and short selling. While the KRX post the short selling volume of the previous day, it needs to provide more information including the total short interests and the short interest of each stock.

Second, the opposite effect of short selling stock prices in the KRX and the NYSE indicates a need for follow-up studies on characteristics of policies in both exchanges. This shows that the difference in information provided through public posting can lead to a difference in market reaction. The KRX publicly posts daily volume and amount of SLB transactions. It also posts daily volume and balance of credit and LBR transactions, but for short selling transactions, only the volume, not the balance, is posted. This posting system needs to be reviewed. In addition, the effect of the latest policy revision in the KRX (increased the daily price limits by $\pm 30 \%$ in June 2015 and started to post the short interests in July 2016) needs to be further investigated.

This study is limited since the short selling volume in the KRX is compiled for the $15^{\text {th }}$ and the last day of the month to align it with the NYSE volume. We also use the short selling balance of NYSE and the short selling transaction volume of the KRX to calculate SSR. For future direction of research, we recommend a follow-up study to address the limitations when the KRX adopts the same posting system used in the NYSE.

\section{Acknowledgement}

We gratefully acknowledge the National Research Foundation of Korea. We are also grateful to an anonymous reviewer whose guidance and comments significantly improve the paper.

\section{Funding Information}

This work was supported by the National Research Foundation of Korea Grant funded by the Korean Government. (NRF-2014-013-2014S1A2A1A01026028).

\section{Author's Contributions}

Yeongsuk Cho: Contributed to the writing of the manuscript, designed and coordinated research plan and organized the study. Responsible for data collection and provided the qualitative research design and analysis. Reviewed and revised the manuscript.
Youngsik Kwak: Contributed to the data analysis. Provided research findings and designed the research methodology. Reviewed and revised the manuscript.

\section{Ethics}

This article is original and contains unpublished material. The corresponding author confirms that the other author have read and approved the manuscript and no ethical issues involved.

\section{References}

Adams, J.C., S.A. Mansi and T. Nishikawa, 2014. Affiliated agents, boards of directors and mutual fund securities lending returns. J. Financial Res., 37: 461-494. DOI: 10.1111/jfir.12043

Aitken, M.J., A. Frino, M.S. McCorry and P.L. Swan, 1998. Short Sales are almost instantaneously bad news: Evidence from the Australian stock exchange. J. Finance, 53: 2205-2223. DOI: $10.1111 / 0022-1082.00088$

Allen, F., S. Morris and A. Postlewaite, 1992. Inite bubbles with short sale constraints and asymmetric information. J. Econ. Theory, 61: 206-229. DOI: $10.1006 /$ jeth. 1993.1067

Autore, D.M., R.S. Billingsley and M.I. Schneller, 2009. Information uncertainty and auditor reputation. J. Bank. Finance, 33: 183-192. DOI: $10.1016 /$ j.jbankfin.2008.07.011

Beber, A. and M. Pagano, 2013. Short-selling bans around the world: Evidence from the 2007-09 Crisis. J. Finance, 68: 343-381. DOI: $10.1111 / \mathrm{j} .1540-6261.2012 .01802 . \mathrm{x}$

Boehme, D.R., R.B. Danielson and M.S. Sorescu, 2006. Short Sale constraints differences of opinion and overvaluation. J. Financial Quantitative Anal., 41: 455-487. DOI: 10.1017/S0022109000002143

Boehmer, E., C.M. Jones and X. Zhang, 2008. Which shorts are informed? J. Finance, 63: 491-528. DOI: $10.1111 /$ j.1540-6261.2008.01324.x

Boulton, T.J. and M.V. Braga-Alves, 2010. The skinny on the 2008 naked short-sale restrictions. J. Financial Markets, 13: 397-421. DOI: $10.1016 /$ j.finmar.2010.05.002

Brent, A., D. Morse and E.K. Stice, 1990. Short interest: Explanations and tests. J. Financial Quantitative Anal., 25: 273-289. DOI: 10.2307/2330829

Bris, A., W.N. Goetzmann and N. Zhu, 2007. Efficiency and the bear: Short sales and markets around the world. J. Finance, 62: 1029-1079. DOI: $10.1111 /$ j.1540-6261.2007.01230.x

Chang, E.C., J.W. Cheng and Y. Yu, 2007. Short-sales constraints and price discovery: Evidence from the Hong Kong market. J. Finance, 62: 2097-2121. DOI: $10.1111 /$ j.1540-6261.2007.01270.x 
Cho, Y.S. and S.W. Hwang, 2014. Informational content of stock lending and borrowing transactions in Korea. K.J. Financial Eng., 2: 141-171.

Cho, Y.S and Y. Kwak, 2017. Information contents of short selling restriction and stock lending and borrowing transactions. Am. J. Econ. Bus. Admin., 9: 27-37.

Cohen, L., K.B. Diether and C.J. Malloy, 2007. Supply and demand shifts in the shorting market. J. Finance, 62: 2061-2096. DOI: $10.1111 / \mathrm{j} .1540-6261.2007 .01269 . \mathrm{x}$

Comerton-Forde, C., B.H. Do, P. Gray and T. Manton, 2016a. Assessing the information content of shortselling metrics using daily disclosures. J. Bank. Finance, 64: 188-204.

DOI: $10.1016 /$ j.jbankfin.2015.12.009

Comerton-Forde, C., C.M. Jones and T.J. Putnins, 2016b. Shorting at close range: A tale of two types. J. Financial Eco., 121: 546-568. DOI: $10.1016 /$ j.jfineco.2016.05.002

Diether, K.B., K. Lee and I.M. Werner, 2009. Short-sale strategies and return predictability. Rev. Financial Stud., 22: 575-607. DOI: 10.1093/rfs/hhn047

Eom, K.S., K.B. Bin and J.S. Kim, 2011. Foreign investors short sales and individual stock prices in the Korean stock marke. Korean J. Financial Stud., 28: 139-187.

Harris, L.E., E. Namvar and B. Phillips, 2013. Price Inflation and wealth transfer during the 2008 SEC Short-Sale Ban. J. Invest. Manage., 11: 5-27.

Henry, O.T. and M. McKenzie, 2006. The impact of short selling on the price-volume relationship: Evidence from Hong Kong. J. Bus., 2: 671-692. DOI: $10.1086 / 499135$

Hurtado Sanchez, L., 1978. Short-interest: Its Influence as a stabilizer of stock return. J. Financial Quantitative Anal., 13: 965-985. DOI: 10.2307/2330638

Hwang, S.W. and Y.S. Cho, 2011. A Study on the relationship between stock lending and borrowing transactions and stock market volatility. Korean J. Financial Manage., 28: 11-38.
Hwang, S.W. and Y.S. Cho, 2012. Stock lending and borrowing transactions and capital market liquidit. Korean J. Financial Eng., 1: 83-104.

Jones, C.M. and O.A. Lamont, 2002. Short-sale constraints and stock returns. J. Financial Econ., 66: 207-239. DOI: 10.1016/S0304-405X(02)00224-6

Kaplan, S.N., T.J. Moskowitz and B.A. Sensoy, 2013. The effects of stock lending on security prices: An experimen. J. Finance, 68: 1891-1936. DOI: $10.1111 /$ jofi.12051

Kim, J.O., 2000. An empirical investigation of short sales: Evidence from the Korea stock market. Korean J. Financial Stud., 26: 343-397.

Kim, J.S., 2010. An analysis on the influences of shortselling bans in Korea stock market. Capital MarketPERSPECTIVE. 2:49-59.

Kim, J.S. and K.B. Bin, 2009. Major issue and policy implications of short-selling in Korea exchange. Issue Paper9(4), Korea Capital Market Institute.

Nagel, S., 2005. Short Sales, Institutional investors and the cross-sectional of stock returns. J. Financial Econ., 78: 277-309. DOI: $10.1016 /$ j.jfineco.2004.08.008

Song, C.S., 2006. Motives for short Selling from securities Lending and stock returns. Asia-Pacific J. Financial Stud., 35: 1-37.

$\mathrm{Wu}, \mathrm{L} ., \mathrm{H}$. Luo and Z. Fu, 2018. Positive returnvolatility correlation and short sale constraints: Evidence from the Chinese market. Asia-Pacific Financial Stud., 47: 132-157.

DOI: $10.1111 /$ ajfs. 12204

\section{Source}

Figure 1:

* Source: Korea Financial Investment Association (freesis.kofia.or.kr) 